President Mitterrand were only half serious, he may nevertheless have hit on a way that will appeal to others of circumventing present impediments in Europe. The best hope at Fontainebleau is that both the British and their detractors will find some way of bridging the gap between short and long-term interests. The best field in which to look for a bridging formula is that for wringing from Europe's academic and research institutions the promise of which they are richly capable.

\section{One treaty to sign}

\section{One or other of the nuclear powers should urge that the threshold test-ban treaty be ratified.}

ON the face of things, there seems no prospect of an early improvement in relations between the Soviet Union and the West. Even the proposal that the president of the US National Academy of Sciences, Dr Frank Press, should go to Moscow to try out some unspecified plans for further collaboration has been put off by accumulating doubts about the welfare of the Sakharovs (see p.485). This week's economic summit in London, which has brought together many of those who might have been able to influence events, was constructed around a different agenda (and a pretty empty one at that). Next will come the Northern Hemisphere's vacations and then the presidential election campaign in the United States, into which President Reagan will plunge without the once-hoped-for deal with the Soviet Union on some form of arms control. On present form, it will be a full year before anybody who matters will be in a frame of mind to take constructive steps.

Here, then, is a simple recipe for action now, not sometime in the future: dust off the Threshold Test-Ban Treaty and see that it is ratified by the United States and the Soviet Union. The treaty has been signed for the past decade, since when both the major nuclear powers have publicly insisted that they have kept to the letter of the treaty, which forbids the testing of weapons yielding more than the equivalent of 150,000 tons of conventional explosive. (Because of the earlier partial test-ban treaty, such tests must of course be underground.) While there have been complaints in the past few years, especially from the United States, that the treaty has been violated, the seismic evidence on this point is inconclusive or, more accurately, is consistent with the view that both the major powers have kept their unratified bargain with each other and the rest of us.

So why bother to ratify the treaty, in the process running the risk of a refusal by the US Congress? There are several practical reasons, not the least of which is that the full text of the treaty includes provisions for the exchange of seismic data about the neighbourhood of known testing sites that make the remote monitoring of other people's nuclear explosions less ambiguous, perhaps much more precise. It seems strange that neither of the major powers has sought to reap these benefits - or to shame the other by provoking a public declaration of unwillingness to ratify an otherwise agreed document. That, however, is only one of a long list of reasons why reasonable powers should legally endorse a reasonable document.

The threshold treaty may be a pale shadow of, say, an agreement on European missiles or a further instalment of the strategic arms agreements, but it has been negotiated and the others have not. And while it may not obviously be the "substantial" step towards strategic arms control required of the nuclear powers by the non-proliferation treaty, it is much more than the nothing that, on present form, the nuclear powers will have to report to next year's review conference of that treaty. Finally, the threshold treaty offers obvious scope for extension - reductions of the threshold, remote but on-site inspection - that could help to provide later and more ambitious agreements. It should not have escaped the US Administration's notice that a ratified agreement would also give the president something to boast about in November. The trouble is that there is very little time to act, with the party conventions in the United States only weeks away. That is another argument for moving quickly.

\section{Shoestring research}

\section{The problems of British research are epitomized} by this week's closure of a laboratory.

WHILE nobody is conspicuously to blame that one of the bestknown British laboratories in the neurosciences is to be closed (see p.486), the affair should give pause to those responsible for the management of research in countries such as Britiain, but in Britain in particular. And while the Medical Research Council (MRC) is on this occasion lucklessly responsible, there is every reason to expect the laboratories under the wings of other organizations will similarly find themselves in trouble when the time comes to replace a director who has decided (for good personal reasons) to quit. What has happened is a depressing symptom of what is wrong with the condition of British science.

The MRC Neurochemical Pharmacology Unit has its origins in the council's general policy, going back to before the Second World War, that research can be powerfully stimulated in important fields by providing a scientist of distinction with a good laboratory and a team of close colleagues with whom he can expect to work for decades to come. Of necessity, these units are small and also impermanent. If the good scientist should die, retire or simply quit, the case for the perpetuation of the unit may disappear at the same time. Ironically, the Cambridge unit partly owes its existence to the disappointment caused twenty years ago by the departure for the United States of the then newly appointed head of a similar initiative at the University of Birmingham. On this occasion, the council seems sensibly to have decided that the work of its unit at Cambridge was important enough to justify the search for a successor to the departed director. The outcome, by all accounts, has been disappointing. Part of the trouble seems to have been the search committee's confusion about its objectives. Should it seek a more or less classical pharmacologist? An up-todate neuroanatomist? Or a molecular biologist? The difficulties seem to have been aggravated by some candidates' agony in making up their minds and by other people's choosiness about candidates with whom they would or would not work. In the event, the mere passage of time seems to have put paid to the hope that the unit could be kept alive.

Recriminations will now abound, but are inappropriate. To spend more than two years looking for a suitable person and then to fail to find one may betoken indecisiveness but is more vividly a proof that Britain, even Cambridge, is no longer a kind of mecca for professional people from elsewhere. Those who think otherwise might reflect on the recent fall in the value of the pound sterling (at or below $\$ 1.40$ ), but there are more serious difficulties. A unit of a dozen or so people may be able to make an important mark in some chosen field if it has been welded together by some central instigator, but is otherwise probably too small to be able to hold its own against the competition. An attempt to create in Britain a unit on a scale that would be capable of holding its own in the exciting but competitive game of telling which genes do what in neurones would be doomed to failure now that speed in working out the nucleotide sequence of a gene has apparently became crucial. The particular lesson for MRC is a further narrowing of the scope for setting up research units on the nowfamiliar pattern. And just as the Science and Engineering Research Council is being forced by circumstances to reconsider its role in the support of high-energy physics, so MRC may soon find that some fields of once-cheap research are beyond its means.

The other lesson, for British research managers of all kinds, is the importance of flexibility. Historically, MRC's units have been successful because it has been possible to found them quickly in emerging fields of interest, and without uprooting people in the process. There will no doubt continue to be scope for entrepreneurship of that kind. But if competitiveness is important, there can be no preordained pattern or scale for the operation of such units. Those which succeed must be encouraged to grow, even in directions not foreseen. Others, less successful than the Cambridge laboratory, must be allowed to lapse. Doing nothing is the worst policy. 